\title{
Adenoviral Infections in Pediatric Liver Transplant Recipients
}

\author{
Dr. Baburao Koneru, MD, Dr. Ronald Jaffe, MB, BCh, Dr. Carlos O. Esquivel, MD, PhD, Dr. \\ Rainer Kunz, MD, Dr. Satuoro Todo, MD, Dr. Shunzaburo Iwatsuki, MD, and Dr. Thomas E. \\ Starzl, MD, PhD \\ Departments of Surgery (Drs Koneru, Esquivel, Todo, Iwatsuki, and Starzl) and Pathology (Dr Jaffe), \\ University of Pittsburgh; and the Department of Surgery, University of Ulm, Ulm, West Germany (Dr \\ Kunz)
}

\section{Abstract}

Over a 51/2-year period, 22 of 262 children receiving liver transplants developed adenoviral infections. Five had adenoviral hepatitis in the allograft, caused by serotype 5 . All five were treated for rejection, either just before or at the time of infection. Liver biopsy specimens had characteristic histological appearance, and diagnosis of adenoviral infection was confirmed with monoclonal anti-adenoviral antibodies, electron microscopy, and by culture of liver tissue. In the remaining 17 patients, adenovirus was isolated from urine, stool, throat secretions, and/or blood samples, but none had any detectable visceral infection. Serotypes 1 and 2 predominated, similar to children not receiving transplants during the same time period. Three of the patients with hepatitis are alive and well; two died of liver failure. Adenoviral hepatitis did not recur in the second allograft of a patient who underwent retransplantation for combined rejection and adenoviral hepatitis, and appears, therefore, not to be a contraindication to retransplantation when liver failure ensues.

Since they were first isolated from human tissues in $1953,{ }^{1}$ adenoviruses (AVs) have been shown to cause a wide spectrum of illness. Common forms of infection are pharyngitis, conjunctivitis, gastroenteritis, and pneumonia. It is believed that AVs cause $10 \%$ of pneumonias that require hospitalization in children ${ }^{2}$ and that by age 5 years every child has had at least one episode of $\mathrm{AV}$ infection. ${ }^{3}$ To date, 41 serotypes have been identified, ${ }^{4}$ and serotypes 1 to 3,5 to 7 , and 21 are the most common pathogens in children. ${ }^{2}$ Adenoviruses have been reported on occasion to cause fulminant hepatitis and other disseminated infections, mostly in immunocompromised patients, ${ }^{5-7}$ including renal and bone marrow transplant recipients. ${ }^{8-12}$ There is a case report of a lethal $\mathrm{AV}$ infection following a fetal liver transplant for severe combined immunodeficiency. ${ }^{13}$ A recent fatal AV hepatitis following orthotopic liver transplant in a child in our institution prompted us to review our experience with these infections in pediatric recipients of orthotopic liver transplants.

\section{METHODS}

The records of the virology laboratory at Children's Hospital of Pittsburgh were reviewed and all patients, including those receiving liver transplants from whom AV was isolated between March 1981 and September 1986 were identified. Clinical data of all patients with orthotopic liver transplants having AV infections were reviewed, with particular attention paid to the interval between transplantation and onset of infection, the relationship of rejection and its treatment to infection, other concomitant viral infections, and the clinical features of AV infections. All available, pertinent pathology material was reviewed by one of us (R.J.). 
Information regarding the site and serotype of $\mathrm{AV}$ was obtained for the nontransplant population.

\section{Viral Procedures}

Throat swab, urine, and blood specimens were sent for virologic culture every two weeks in all children with liver transplants as part of viral surveillance and during the investigation of any febrile episode (temperature of $38.5^{\circ} \mathrm{C}$ or more). Stool samples were sent only when patients developed diarrhea. Beginning in June 1985, liver tissue from biopsy specimens was sent routinely for viral culture. Urine and throat swab specimens were sent in viral transport medium containing a balanced salt solution, gelatin, and antibiotics. Blood was sent in a heparinized specimen tube; the buffy coat was separated and resuspended in viral transport medium. Liver tissue, submitted in a petri dish with saline, was ground with a mortar and centrifuged and the supernatant was added to viral transport medium. Specimens in viral transport medium were inoculated into commercially prepared cell culture tubes. One tube each of African green monkey kidney and HEp-2 cells and two tubes of human foreskin fibroblasts were used. Liver tissue was also inoculated into Rhesus monkey kidney and WI-38 cells. Cell culture tubes were maintained at $37^{\circ} \mathrm{C}$ and observed periodically for cytopathic effects. Cytomegalovirus (CMV) and herpes simplex were identified by their cytopathic effect alone. Suspected AV isolates were identified and typed at the Allegheny County (Pittsburgh) Laboratories using neutralization with antisera obtained from the Centers for Disease Control, on African green monkey kidney and HEp-2 cells.

\section{Pathological Studies}

Liver tissue was processed for light microscopy and a portion was snap frozen in a cryoprotective medium and stored at $-70^{\circ} \mathrm{C}$. Frozen sections were stained using an avidinbiotin peroxidase method with monoclonal anti-AV antibody (MA805) and anti-CMV antibody (MA810). The anti-AV antibody crossreacts with all serotypes and the anti-CMV antibody recognized an early antigen. Appropriate biologic positive and negative controls were used. Sections for electron microscopy were fixed in $2 \%$ glutaraldehyde, embedded in epoxy resin and examined with a Phillips II microscope.

\section{RESULTS}

During the 51/2-year study period 262 children received orthotopic liver transplants. Immunosuppression was with cyclosporin and steroids. Rejection episodes were treated with additional steroids, monoclonal antibody OKT3, or both. Twenty-two patients (8.4\%) had AV isolated from different sites. These patients were divided into two groups based on the type of infection.

\section{Group 1}

All five patients in this group (Table 1) had hepatitis caused by AV serotype $5\left(\mathrm{AV}_{5}\right)$ within an interval of 12 to 30 days following the transplant. All five had received treatment for suspected rejection either concurrently with the AV infection or shortly preceding it. Three of the five had the rejection episode treated with OKT3 in addition to other therapy. Four of the five patients showed growth of $\mathrm{AV}_{5}$ in other sites in addition to liver (blood, urine, and throat), but none had any other parenchymal organ involvement. Two of the five also had CMV infection while in three AV was the only viral infection. All had elevated serum transaminase levels and severe systemic symptoms (eg, temperatures to $40^{\circ} \mathrm{C}$ and chills) but only in one could the fevers be attributed entirely to AV as the others had, in addition, rejection or other infections. The diagnosis in all five was suspected by histological findings (four biopsy specimens and one hepatectomy specimen at retransplantation), and was confirmed by ancillary means. The patient undergoing retransplantation had both AV infection and rejection 
in the removed allograft. Three of the five patients are alive and well; two patients died of fulminant liver failure with coagulopathy and of gastrointestinal tract bleeding. Autopsies were performed on both.

The features in all five cases were highly distinctive and virtually identical. Punched-out, circumscribed lesions were scattered randomly in the hepatic parenchyma with no fixed relation to portal areas (Fig 1, left). These lesions had some necrosis but less than that seen in herpetic lesions. Instead, they were filled with monocytes and neutrophils (Fig 1, center), confirmed by the demonstration of large amounts of lysozyme in the mononuclear and granular cells (Fig 1, right) and with monoclonal antibody FMC-17 against monocytes-macrophages. Very few T cells were seen in the lesions, using the pan T-cell marker, T11.

Hepatocytes at the edges of the lesions were slightly enlarged without multinucleation. Only a few cells contained intranuclear inclusions, most of which were stellate or cruciate amphophilic bodies (Fig 2, left). Monoclonal antibody to AV was intensely reactive with the nucleus and cytoplasm of cells in and around the lesions but with few cells outside of the lesions (Fig 2, right). There was no reaction with antibody to herpes simplex or CMV except in one instance (to be described later). In one child who died of AV hepatitis, autopsy results three days after biopsy showed progression with a far greater number of punched-out lesions, extensive, almost confluent necrosis, and fewer monocytes and neutrophils. No AV was detected by microscopy outside of the liver. In the second patient, who died 15 days after diagnosis, autopsy results showed extensive hepatic necrosis, but only a minimal amount of viral antigen was demonstrable in liver tissue and no other organ involvement was detected.

Adenovirus was confirmed in the lesions by immunostaining of frozen liver tissue in the four cases tested (Fig 2, right). Viral particles 65 to $90 \mathrm{~nm}$ in size were seen in the four cases examined by electron microscopy. Adenovirus and CMV were found together in one lesion. In this instance, characteristic necrotizing lesions were found in which CMV was demonstrable by microscopy and confirmed by immunostaining. Since this type of granulomatous, monocyte-filled lesion is not characteristic of CMV infection, another virus was suspected and $\mathrm{AV}$ was detected in the lifted sections. Adenovirus serotype 5 was cultured from liver biopsy specimens in all five patients.

\section{Group 2}

Seventeen patients aged 8 months through 10 years had AV on culture of different body fluids (urine, stool, throat secretions, and/or blood), but without any detectable visceral infection (Table 2). One was a preoperative throat specimen. The other 16 developed infection five days to two years following orthotopic liver transplants. Seven had $\mathrm{AV}_{1}$ isolates, four, $\mathrm{AV}_{2}$; two, $\mathrm{AV}_{5}$; and one, $\mathrm{AV}_{7}$. In three patients the $\mathrm{AV}$ isolate was untyped. Nine of 17 had other viral infections (CMV, six; herpes simplex, two; and Epstein-Barr virus, three). Eleven of the 17 had liver biopsies close to the time of the AV isolation, but none showed hepatitis. Eleven of these 17 patients are alive and well. One has chronic rejection; two patients who earlier had Epstein-Barr virus infections developed Epstein-Barr virus-related lymphoproliferative disorders. Three patients died, none as a result of AV infection.

\section{Children Not Receiving Transplants}

During the study period there were $47 \mathrm{AV}$ isolates from 43 patients (Table 3). Of the isolates, $A V_{1}$, and $A V_{2}$ formed $45 \%$, and $A V_{5}$ formed $7 \%$. 


\section{COMMENT}

The incidence of AV infections in our patients was $8.4 \%$. This could be an underestimate, because viral cultures were not pursued aggressively in the investigation of a febrile episode earlier on. Also, the use of other media, such as primary or transformed human embryonic kidney cells for viral isolation may have yielded a higher incidence of positive cultures. The same applies to the culturing of liver tissue. The incidence of AV hepatitis was 1.9\%, but it is possible that some were missed because it is very difficult to differentiate clinically between rejection and hepatitis, and some patients with hepatitis may not have undergone biopsy. Shields et al ${ }^{10}$ noted a $4.9 \%$ overall incidence of AV infections in 1051 bone marrow recipients of all ages. Visceral infections accounted for $0.95 \%$; two of those had AV hepatitis.

Percutaneous liver biopsy is the most definitive way of diagnosing AV hepatitis. Without this, it may be mistakenly treated as rejection, with detrimental effects. The histological features of AV hepatitis reported in the literature have been those of advanced disease, ${ }^{5,6,14}$ showing considerable necrosis. The histological appearance we have described is thus characteristic, allowing a presumptive diagnosis to be made on morphological grounds alone. This can be confirmed rapidly and economically by immunoenzyme staining using monoclonal anti-AV antibodies. Electron microscopy is not required routinely. The diagnosis can be made within hours, long before viral cultures of the liver biopsy specimen are definitive, which may take several days.

All hepatitis cases in our series were due to $A V_{5}$. Experimentally, human $A V_{5}$ has been shown to cause fulminant hepatitis in newborn hamsters and mice. ${ }^{15,16}$ Some of the AV hepatitis cases reported in the literature were also caused by $\mathrm{AV}_{5}{ }^{7,10,11}$ Thus, $\mathrm{AV}_{5}$ may have greater propensity to cause hepatitis than other serotypes, at least in children.

The significance of the AV isolations in group 2 patients is not clear. Even though several of these patients had fevers, it is difficult to attribute them solely to AV infections, as other causes coexisted. It can be argued that some of these are not new AV infections but are episodes of temporary virus shedding following an AV infection in the recent past. This has been shown to happen following enteric and respiratory $\mathrm{AV}$ infections in normal children. ${ }^{17}$

The serotypes isolated in group 2 are similar to the pattern of isolates in the general pediatric population, where $\mathrm{AV}_{1}$ and $\mathrm{AV}_{2}$ accounted for $60 \%$ of isolates. ${ }^{2}$ In contrast to the studies of Shields et al ${ }^{10}$ in bone marrow transplants, and Horowitz et al, ${ }^{18}$ in patients with the acquired immunodeficiency syndrome, we did not find any $\mathrm{AV}_{35}$ isolates at all. We do not know at present what determines the onset of hepatitis in a given patient with AV infection.

These infections must have been either exogenously acquired or followed reactivation of latent virus present in the tissues (transplanted organ or recipient's own) after a remote infection. There was no calendar clustering of cases to suspect a common external source. There is ample evidence to suggest that $\mathrm{AV}$ can remain latent in tonsils and adenoids, ${ }^{19}$ and, latency has been suggested in kidneys also. ${ }^{12}$ In vitro cultures of human umbilical cord mononuclear leukocytes have shown that $\mathrm{AV}_{5}$ and $\mathrm{AV}_{6}$ can infect and remain in these cells for months, either alone or when the leukocytes have been previously infected by Epstein-Barr virus. ${ }^{20,21}$ There were three patients in our study who had Epstein-Barr virus and AV infections together, reflecting such an association or a general immunosuppressed state. It has been suggested that the virus may be reactivated from within the recipient's activated lymphocytes in a rejection process.

${ }^{22}$ Shields et al ${ }^{23}$ have shown that reactivation of latent virus in the recipient's tissue is a strong possibility because in 15 bone marrow recipients with AV infections, 12 had neutralizing antibodies in pre-transplant serum samples. It is not known whether AV infection can initiate allograft rejection, but CMV infections have been implicated in causing allograft rejection. ${ }^{24}$ 
Most of the patients with AV hepatitis reported in the literature have died ${ }^{5-7,14,25}$ with coagulopathy, encephalopathy, and gastrointestinal tract bleeding. The absence of any specific chemotherapeutic agent effective against AV limits treatment options. There are two single case reports of serious AV infections successfully treated, one with thymic humoral factor ${ }^{26}$ and the other, an $\mathrm{AV}_{5}$ infection, with immune serum globulin containing high titer of neutralizing antibody to $\mathrm{AV}_{5} \cdot{ }^{27}$ Our policy in treating these patients was to decrease the immunosuppression, trying to achieve a delicate balance between treating rejection and infection. Three of our five patients with hepatitis are alive and well at home. One of the patients had very rapid progression to fulminant hepatitis and died in a few days. The other patient who survived for 15 days following the onset of hepatitis had only a minimal amount of virus demonstrable in the liver at the time of autopsy and may have lived had we been able to retransplant the liver. It is noteworthy that the child with the mixed picture of rejection and AV hepatitis did not develop recurrent AV infection in the new allograft after retransplantation.

\section{Acknowledgments}

This work was supported in part by research grants from the Veterans Administration, and project grant AM-29961 from the National Institutes of Health.

The authors are very grateful for the help provided by Richard Debiaso, MS, and Abid Rahman, MS, in the virology laboratory of Children's Hospital of Pittsburgh.

\section{References}

1. Rowe WP, Huebner RJ, Gilmore LK, et al. Isolation of a cytopathogenic agent from human adenoids undergoing spontaneous degeneration in tissue culture. Proc Soc Exp Biol Med 1953;84:570-573. [PubMed: 13134217]

2. Brandt CD, Kim HW, Vargosko AJ, et al. Infections in 18000 infants and children in a controlled study of respiratory tract disease: I. Adenovirus pathogenicity in relation to serological type and illness syndrome. Am J Epidemiol 1969;90:484-500. [PubMed: 4312064]

3. Chanock RM. Impact of adenoviruses in human disease. Prev Med 1974;3:466-472. [PubMed: 4373701]

4. DeJong JC, Wigand R, Kidd AH, et al. Candidate adenoviruses 40 and 41, fastidious adenoviruses from human infant stool. J Med Virol 1983;11:215-231. [PubMed: 6306161]

5. Aterman K, Embil J, Easterbrook KB, et al. Liver necrosis: Adenovirus type 2 and thymic dysplasia. Virchows Arch A 1973;360:155-171.

6. Wigger JH, Blanc WA. Fatal hepatic and bronchial necrosis in adenovirus infection with thymic alymphoplasia. N Engl J Med 1966;275:870-874. [PubMed: 4288677]

7. Zhradnik JM, Spencer MJ, Porter DD. Adenovirus infection in the immunocompromised patient. Am J Med 1980;68:725-732. [PubMed: 6246799]

8. Fiala M, Payne JE, Berne TV, et al. Role of adenovirus type 11 in hemorrhagic cystitis secondary to immunosuppression. J Urol 1974;112:595-597. [PubMed: 4607419]

9. Keller EW, Rubin RH, Black PH, et al. Isolation of adenovirus type 34 from a renal transplant recipient with interstitial pneumonia. Transplantation 1977;23:188-191. [PubMed: 189468]

10. Shields AF, Hackman RC, Fife KH, et al. Adenovirus infections in patients undergoing bone marrow transplantation. N Engl J Med 1985;312:529-533. [PubMed: 2982098]

11. Purtillo DT, White R, Filipovich A, et al. Fulminant liver failure induced by adenovirus after bone marrow transplantation. N Engl J Med 1985;312:1707-1708.

12. Stalder H, Hierholzer JC, Oxman MN. New human adenovirus (candidate adenovirus type 35) causing fatal disseminated infection in a renal transplant recipient. J Clin Microbiol 1977;6:257-265. 366376. [PubMed: 71305]

13. Rodriguez FH, Liuzza GE, Gohd RH. Disseminated adenovirus serotype 31 infection in an immunocompromised host. Am J Clin Pathol 1984;82:615-618. [PubMed: 6093498] 
14. South MA, Dolen J, Beach DK, et al. Fatal adenovirus hepatic necrosis in severe combined immunodeficiency. Pediatr Infect Dis 1982;6:416-419. [PubMed: 6298755]

15. Perreira HG, Allison AC, Niven JSF. Fatal infection of newborn hamsters by an adenovirus of human origin. Nature 1962;196:244-245.

16. Postlethwaite R. Liver damage induced in mice by human adenovirus type 5. Scott Med J 1973;18:131.

17. Fox JP, Hall CE, Cooney MK. The Seattle virus watch: VII. Observations of adenovirus infections. Am J Epidemiol 1977;105:362-386. [PubMed: 192073]

18. Horwitz MS, Valderrama G, Hatcher V, et al. Characterization of adenovirus isolates from AIDS patients. Ann NY Acad Sci 1985;437:161-174. [PubMed: 6099998]

19. Huebner RJ, Rowe WP, Panott TG, et al. Adenoidal-pharyngeal-conjunctival agents: A newly recognized group of common viruses of the respiratory system. N Engl J Med 1954;251:1077-1086. [PubMed: 13223958]

20. Andiman WA, Miller G. Persistent infection with adenovirus types 5 and 6 in lymphoid cells from humans and woolly monkeys. J Infect Dis 1982;145:83-88. [PubMed: 6274968]

21. Faucon N, Desgranges C. Persistence of human adenovirus 5 in human cord blood lymphoblastoid cell lines transformed by Epstein-Barr virus. Infect Immun 1980;29:1180-1184. [PubMed: 6253398]

22. Hirsch, MS. Immune activation of endogenous viruses. In: Crowell, R.; Friedman, H.; Prier, J., editors. Tumor Virus Infections and Immunity. Baltimore: University Park Press; 1976. p. 175

23. Shields AF, Hackman RC, Fife KH, et al. Fulminant liver failure induced by adrenal virus after bone marrow transplantation, letter to the editor. N Engl J Med 1985;312:1708. [PubMed: 3889644]

24. Lopez C, Simmons RL, Mauer SM, et al. Association of renal allograft rejection with virus infections. Am J Med 1974;56:280-289. [PubMed: 4360465]

25. Fadden H, Gallagher M. Disseminated infection due to adenovirus type 4. Clin Pediatr 1980;19:427429.

26. Varsano I, Schonfeld TM, Matoth Y, et al. Severe disseminated adenovirus infection successfully treated with a thymic humoral factor THF. Acta Paediatr Scand 1977;66:329-331. [PubMed: 194457]

27. Dagan R, Schwartz RH, Insel RA, et al. Severe diffuse adenovirus 7a pneumonia in a child with combined immunodeficiency: Possible therapeutic effect of human serum globulin containing a specific neutralizing antibody. Pediatr Infect Dis 1984;3:246-251. [PubMed: 6330708] 


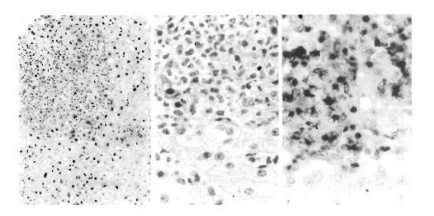

Fig 1.

Adenovirus hepatitis, Left, Fairly circumscribed, punched-out lesions are filled with inflammatory cells (hematoxylin-eosin, original magnification $\times 97$ ). Center, Inflammatory cell population consists of cells with oval or segmented nuclei. Necrosis is not conspicuous and nuclear inclusions may be hard to find (hematoxyhn-eosin, original. magnification $\times 250$ ). Right, Staining of inflammatory cells with antilysozyme reveals dense, nongranular cytoplasmic distribution characteristic of monocytes (diaminobenzidine, original magnification $\times 330)$. 


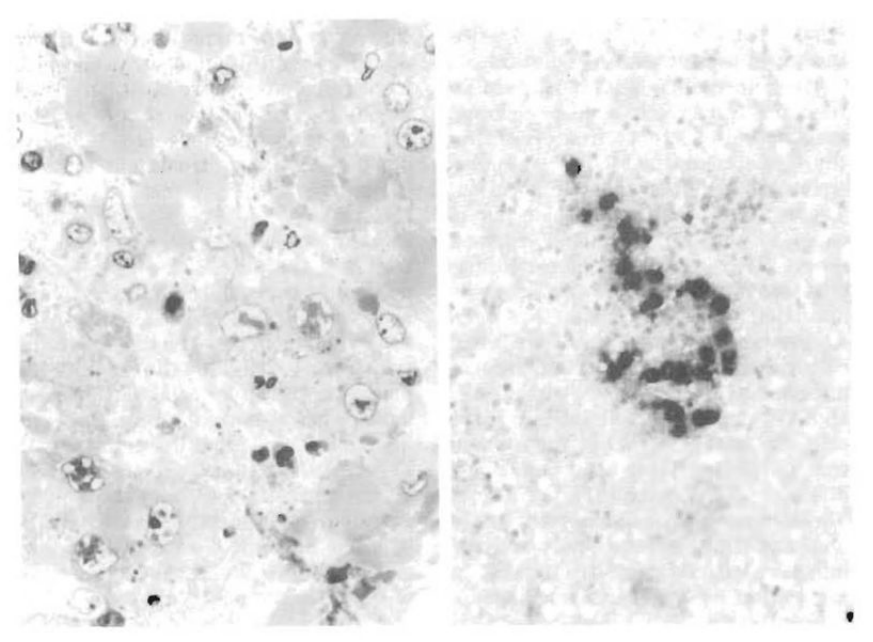

Fig 2.

Adenovirus hepatitis, Left, Case 1 (autopsy), infected nuclei are larger than uninfected ones. Nuclear "inclusions" consist of a patchwork of waxy-appearing dense material with unstained clear zones $(1 \mu \mathrm{m})$ (polychrome, original magnification $\times 330$ ). Right, Case 1 (biopsy specimen) frozen section of liver with a granuloma. Section has been stained with antiadenovirus monoclonal antibody, revealing dense reaction product in enlarged hepatocytes (amino-ethylcarbazol, original magnification $\times 97$ ). 


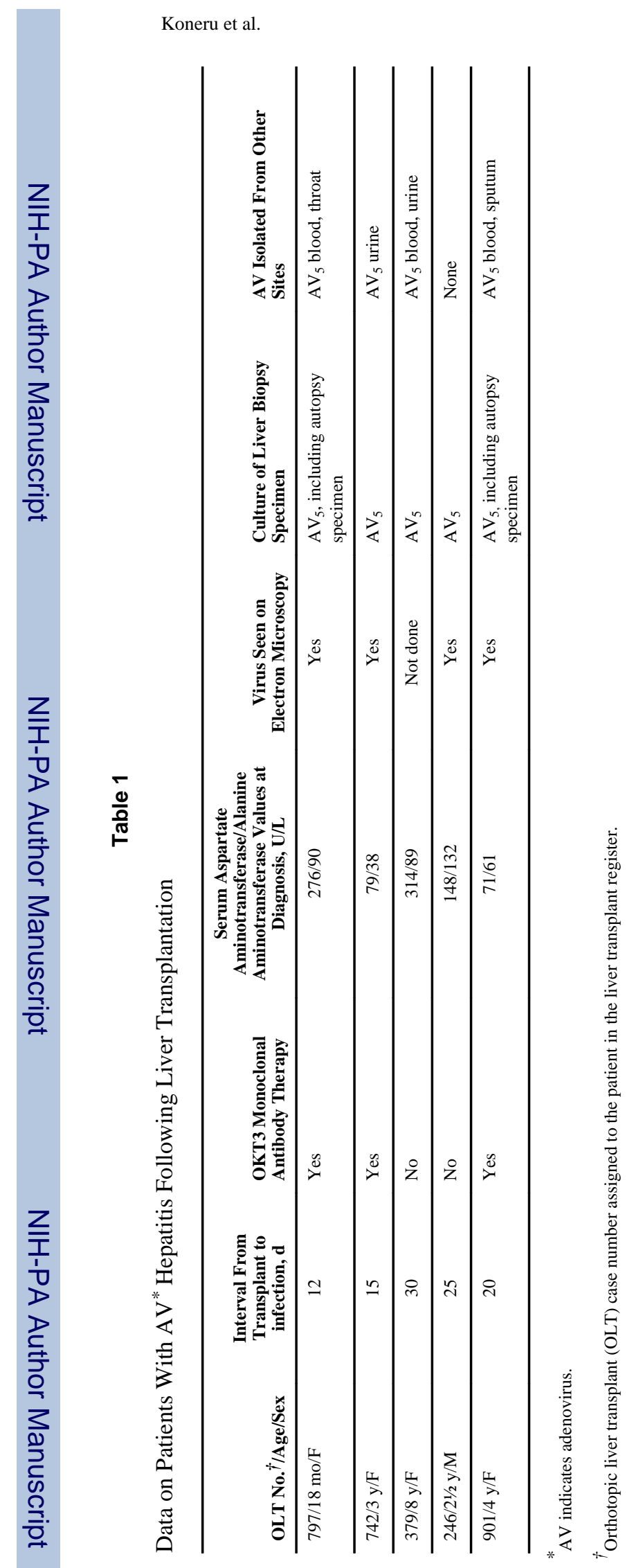

Page 9 
Table 2

Clinical Characteristics of 17 Patients in Group 2 Who Had AV* Infections Without Hepatitis

\begin{tabular}{lc}
\hline Clinical Characteristics & No. of Patients \\
\hline Fever & 12 \\
Other viral infections & $9^{\dagger}$ \\
Use of OKT3 before AV infection & 6 \\
Rejection before AV infection & 9 \\
AV 1 and $\mathrm{AV}_{2}$ isolates & 11 \\
$\mathrm{AV}$ isolated from single site (throat, 6; urine, 5; stool, 1) & 12 \\
$\mathrm{AV}$ isolated from multiple sites & 5 \\
\hline$*$ AV indicates adenovirus. & \\
${ }^{\dagger}$ Nine patients had 11 viral infections. &
\end{tabular}


Table 3

Pattern of $\mathrm{AV}^{*}$ Isolates in Children Not Receiving Transplants ${ }^{\dagger}$

\begin{tabular}{|c|c|c|}
\hline AV Serotypest & Site of Isolation & No. of Isolates \\
\hline $\mathrm{AV}_{1}$ & $\begin{array}{l}\text { Pharynx, } 6 \\
\text { Stool, } 4\end{array}$ & 10 \\
\hline $\mathrm{AV}_{2}$ & $\begin{array}{l}\text { Pharynx, } 4 \\
\text { Lymph node, } 1 \\
\text { Stool, } 4\end{array}$ & 9 \\
\hline $\mathrm{AV}_{3}$ & $\begin{array}{l}\text { Pharynx, } 5 \\
\text { Stool, 1 }\end{array}$ & 6 \\
\hline $\mathrm{AV}_{5}$ & $\begin{array}{l}\text { Urine, } 1 \\
\text { Stool, } 2\end{array}$ & 3 \\
\hline $\mathrm{AV}_{6,7,19}$ & $\begin{array}{l}\text { Small bowel, } 1 \\
\text { Conjunctiva, } 2 \\
\text { Nasopharynx, } 1\end{array}$ & 4 \\
\hline $\mathrm{AV}_{8}$ & $\begin{array}{l}\text { Pharynx, } 3 \\
\text { Conjunctiva, } 8\end{array}$ & $11^{\S}$ \\
\hline Untyped AV & $\begin{array}{l}\text { Pharynx, } 1 \\
\text { Conjunctiva, } 1 \\
\text { Stool, } 2\end{array}$ & 4 \\
\hline Total Isolates & & 47 \\
\hline
\end{tabular}

* AV indicates adenovirus.

${ }^{\dagger}$ Between January 1981 and September 1986 at the virology laboratory of the Children's Hospital of Pittsburgh.

${ }^{*} \mathrm{AV}_{1}$ and $A V_{2}$ accounted for $45 \%$ of identified serotypes; and $A V_{5}, 7 \%$ of identified serotypes.

$\S_{\text {These were a cluster of cases in } 1986 .}$ 